\title{
Factors Influencing the Level of Local Participation in Planning and Management of the Planned Salzburger Lungau \& Kärntner Nockberge Biosphere Reserve in Austria
}

\author{
Michael Huber ${ }^{1,2, *}$ and Arne Arnberger ${ }^{1}$ (1) \\ 1 Institute of Landscape Development, Recreation and Conservation Planning, Department of Spatial, \\ Landscape and Infrastructure Sciences, University of Natural Resources and Life Sciences Vienna, \\ Peter Jordan Strasse 82, 1190 Vienna, Austria; arne.arnberger@boku.ac.at \\ 2 E.C.O. Institute of Ecology, Lakeside B07b, 9020 Klagenfurt, Austria \\ * Correspondence: huber@e-c-o.at; Tel.: +43-6503524949
}

check for updates

Citation: Huber, M.; Arnberger, A. Factors Influencing the Level of Local Participation in Planning and Management of the Planned Salzburger Lungau \& Kärntner Nockberge Biosphere Reserve in Austria. Sustainability 2021, 13, 9685. https://doi.org/10.3390/ su13179685

Received: 13 July 2021

Accepted: 26 August 2021

Published: 28 August 2021

Publisher's Note: MDPI stays neutral with regard to jurisdictional claims in published maps and institutional affiliations.

Copyright: (c) 2021 by the authors. Licensee MDPI, Basel, Switzerland. This article is an open access article distributed under the terms and conditions of the Creative Commons Attribution (CC BY) license (https:// creativecommons.org/licenses/by/ $4.0 /)$.

\begin{abstract}
The participation of the local population in the planning and management of biosphere reserves is one of the preconditions for success. While numerous studies underpin its importance, few studies have addressed to what extent participation is desired by local residents and which factors determine the level of participation. A postal survey among local residents $(n=449)$ explored factors influencing their willingness to participate in the planning and management of the Salzburger Lungau \& Kärntner Nockberge Biosphere Reserve in Austria before it was officially recognised by UNESCO. By applying the "Theory of Planned Behaviour", the study found a high willingness to be involved among the local population, but a considerable variance as to what extent. Regression models showed a strong influence of perceived behavioural control and the social environment, whereas the factors identified in previous studies were less relevant. The results show that the readiness to become active seems to be higher than expected by local bodies and more linked to the design of the participatory process or other barriers. The results support the biosphere reserve management in developing appropriate participatory approaches to maximise satisfaction with participation and management success.
\end{abstract}

Keywords: participation; protected area management; place attachment; behaviour; attitudes; theory of planned behaviour

\section{Introduction}

It is widely accepted that community participation is a key factor for success for protected areas in general [1] and for biosphere reserves in particular [2,3]. The importance of participatory approaches is well embedded into international strategies and conventions such as the Aarhus Convention [4], Local Agenda 21 processes, and the UNESCO Lima Action Plan [5]. Consequently, the local participation of stakeholders and the implementation of different governance models have experienced a rapid advancement since the 1990s [6,7] resulting in a wide set of participatory tools for the sustainable management of protected areas [1].

\subsection{Success Factors, Barriers and Limits}

According to the definition of IUCN, successful participation means the full and effective participation of rightsholders and stakeholders in planning and management [1] This includes an enabling political environment [3], an adequate methodological set-up [2] and a supporting social environment [8].

So far, research has identified numerous barriers and limitations [2]. Implementation barriers are often linked to a lack of capacity, time or money [2], heterogeneous groups with differing perspectives [9] or a disabling political environment [2]. Whereas these framework 
conditions have been investigated extensively, the willingness of local stakeholders and residents to become active in a participatory process has been rarely addressed [10].

\subsection{Factors Determining the Willingness to Participate}

Previous studies investigated the willingness of various population segments to participate in village development [8], watershed management [11], forestry management [12] and fisheries [10]. Studies referring to protected area management are scattered, mostly case study based and follow an ex-post research design [2,13]. Participation in the context of this article refers to the intended degree of involvement of local residents in the planning, management and decision-making of the protected area.

Larson and Lach [11] observed that the more intensive the involvement, the lower the interest to participate, as this requires commitment and time. Furthermore, the trust in local administration (in the context of the study local authorities and the biosphere reserve management) $[2,14]$ as well as experience gained in previous participatory processes are crucial for local people to become active [14]. The degree of trust in local authorities can be a key driver and an important predictor $[15,16]$. It is suspected that the decision to participate can be influenced by the social environment in a positive [17] or negative way [8].

A frequently mentioned factor is the level of concern and the potential impact on local livelihoods $[11,18,19]$. In the context of conservation areas or national parks, potential conflicts due to imposed land use changes, human-wildlife conflicts or, in a Central European context, bark beetle manifestations can be a main trigger for becoming active [20]. However, the effect of the level of concern has been viewed controversially [10]. Whereas a high level of concern is considered to be a trigger for becoming active [2], other studies indicate the opposite [21]. Hernes and Metzger [22] identified the values and professional interests of stakeholder groups as important factors to becoming active. A clear understanding of management objectives and information is reported to affect the readiness to act [23]. Previous studies identified personal characteristics such as the readiness to discuss, team spirit and a sense of community $[11,14]$ as relevant individual factors.

The availability of the resources of participants (e.g., mobility, time) is frequently reported to affect participation $[11,17,24]$. Socio-economic variables are frequently mentioned as relevant but often lack significant results $[12,14,25,26]$. Furthermore, the type of participation methods offered need to meet the preferences of the potential participants [13]. A positive attitude towards participation is another important determinant $[11,14]$.

Gender aspects are often considered relevant as in many traditional systems men play a prominent role in decision-making $[25,26]$. Other socio-economic factors include education, with higher education levels favouring participation [10,12].

Place attachment is frequently described as a potential driver to act [27], indicating a link between the decision to participate or not. Borazjani et al. [28] describe strong local bonds and "being native" as having positive effects on the willingness to participate, both to support a conservation area but also to actively oppose it if the population considers a conservation area a threat to their way of living. Reportedly, positive attitudes correlate with the distance of the protected area and potential immediate impacts on rural livelihoods [29]. Thus, a vital link between place attachment and the willingness to participate is likely, but scarcely analysed.

\subsection{The Theory of Planned Behaviour: Assessing the Readiness to Participate}

The Theory of Planned Behaviour (TPB) seeks to explain future actions by considering the behavioural intention as the strongest predicator for future action [30]. It is used to predict different kinds of planned human behaviours based on three main dimensions: attitude towards behaviour (ATB), subjective norms (SN) and perceived behavioural control (PBC) $[28,29]$. ATB refers to the personal assessment of whether a specific behaviour is useful and beneficial or not. Subjective norms describe the individual's perception of whether the behaviour will be positively acknowledged by family, friends and society. 
PBC reflects the perceived personal ability and subjectively perceived barriers to carry out a behaviour.

The theory has been frequently used in different contexts, such as for analysing recycling behaviour [31], and to explain ecological behaviour [32] or behaviour in public spaces [33]. It has not yet been used in the context of participation in protected areas. However, previous research identified that the social environment [8], the attitude towards participation [11] and the perceived ability to participate are important determinants for the willingness to become active [11,17].

\subsection{Research Questions}

Biosphere reserves (BR) are model regions for sustainable development and strive to efficiently work together with communities to promote sustainable development. The UNESCO Seville Strategy [34] considers local participation to be an important success factor $[2,3,35]$. Thus, a core question for biosphere reserves is to what extent, in which stages and how local residents should be involved in planning and management. Despite the importance of participatory approaches as expressed by research, practitioners and international conventions, it still remains unclear which factors influence the willingness to participate and at which degree of involvement into management local residents perceive their participating role as sufficient.

To address this gap, this study applied the Theory of Planned Behaviour [30] in the context of the new formation of a biosphere reserve during the set-up phase. It seeks to analyse the willingness of local residents to participate in the design and later on in the management of the Salzburger Lungau \& Kärntner Nockberge Biosphere Reserve, which was established in 2012. It seeks to also provide baseline information for future studies as the perception and acceptance of biosphere reserves may increase and change over time [36]. The study seeks to answer the following research questions:

Hypothesis 1. To what extent do local residents intend to participate in the planning and management of the biosphere reserve? Previous research has found that the extent of people getting involved decreases with more intense participatory processes. The hypothesis is that there is a decrease in the willingness to participate with an increase in the intensity of involvement.

Hypothesis 2. Which factors are able to explain the intention to participate? In which ways do TPB dimensions, socio-demographics and place attachment influence the intention to participate? Previous research has shown heterogeneous results regarding socio-demographics depending on different cultural or social contexts. Research frequently indicates that high place attachment has a positive influence even though results are not consistent. The hypothesis is that people with high place attachment are more willing to become active, irrespective of their socio-demographic background.

\section{Materials and Methods}

\subsection{Study Area}

The study was conducted in the Salzburg part (Lungau) of the Austrian UNESCO Salzburger Lungau \& Kärntner Nockberge Biosphere Reserve. In line with similar studies [37], the study area was limited to the Salzburg part as both areas have a different conservation history, a separate management body and a different social setting disconnected from each other. Both parts of the BR cooperated during the nomination but participatory efforts took place mostly in the individual parts [38].

The Lungau covers an area of 102,000 hectares in the southeastern part of the province of Salzburg (Figure 1). About 20,000 inhabitants live in 15 communities. 


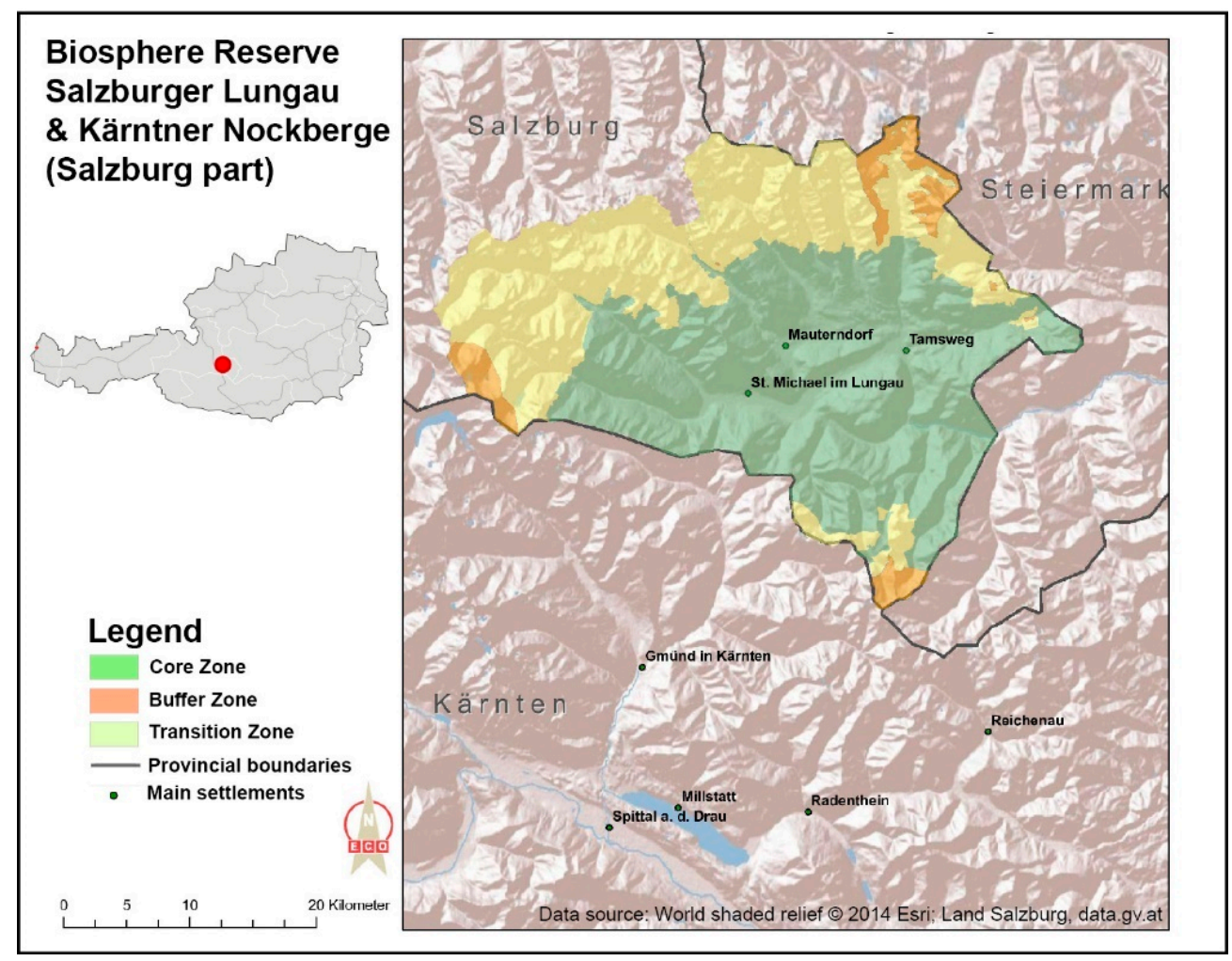

Figure 1. Location of the Salzburger Lungau \& Kärntner Nockberge Biosphere Reserve in Austria. Map only indicates the study area in Salzburg (excluding the adjacent Kärntner Nockberge part south of the study area). (author's draft).

The region is characterised by forests, alpine pastures, farmland and extensive grassland orchards, lakes and wetlands. The regional economy is dominated by tourism, small and medium-sized local enterprises and an agricultural sector with a high proportion of organic small-scale farms.

In 2012, the Salzburger Lungau \& Kärntner Nockberge Biosphere Reserve was listed as a UNESCO biosphere reserve. Prior to the official designation, and in line with the national criteria for UNESCO biosphere reserves, the local authorities carried out an intensive local discussion process to ensure broad support and acceptance. The main reason to apply for a biosphere reserve were the expectations to push sustainable economic development and to gain a competitive advantage for tourism development, whereas conservation considerations played only a minor role. Thus, the overall attitude towards the establishment of the BR was mostly positive [39]. The survey took place in the context of this process to support the local authorities and to design subsequent participatory processes. Up to that point, it remained unclear how to mobilise specific stakeholder groups underrepresented in previous participatory processes carried out in the region [40]. During this phase, there was broad enthusiasm and huge expectations across all stakeholder groups based on the hope that the establishment of a biosphere reserve might trigger dynamic regional development processes [39].

\subsection{Data Collection}

The authors collected the data by a postal survey among the local population in the summer of 2010. During this time, the UNESCO nomination process gained momentum by means of lively local discussions and media coverage. Thus, the interest and general attention of the local population were high and there was a generally positive attitude towards the establishment of a biosphere reserve [39], which was confirmed to have remained stable over time [37]. The results of the survey contributed to the development of a biosphere reserve monitoring scheme for the area [41]. 
A standardised questionnaire was distributed as a supplement to a regional newspaper reaching all 7046 households within the boundaries of the biosphere reserve. To answer, each household was asked to select a household member older than 15 years and who was closest to her/his birthday to complete the survey. The questionnaire consisted of two separate sections addressing the attitude towards the proposed biosphere reserve and the intended degree of participation [39].

In total, 460 questionnaires were returned (response rate: 6.6 percent). The authors excluded 11 cases due to inconsistencies and missing data resulting in a sample size of 449 cases. A crosscheck of the sample with official census data showed that the respondents were older, mostly male and better educated than the average population (see Table 1). People linked to agriculture or tourism, the sectors most closely linked to a biosphere reserve, were overrepresented. As the concept and idea of a biosphere reserve was not yet well rooted in the general population during the time of the survey, this may be an explanation for the relatively low response rate. A certain self-selection effect may have occurred by the fact that only a very small number of opponents responded. However, discussions with the local management body indicated that it seemed plausible as there was a momentum of enthusiasm during the time of the survey.

Table 1. Sample characteristics (sample compared with total population; Statistik Austria, 2009).

\begin{tabular}{|c|c|c|c|}
\hline Variable & Levels & Census & Sample \\
\hline Age & Mean & 39.7 & 47.6 \\
\hline \multirow[t]{2}{*}{ Gender } & Female (\%) & 50.0 & 43.6 \\
\hline & Male (\%) & 50.0 & 56.4 \\
\hline \multirow[t]{7}{*}{ Education } & Primary school/no education & 38.9 & 9.1 \\
\hline & Apprenticeship & & 26.3 \\
\hline & Master Craftsman & 37.0 & 12.2 \\
\hline & Middle school & & 12.2 \\
\hline & A-Levels & 11.6 & 23.3 \\
\hline & University Degree & 7.5 & 13.5 \\
\hline & Other & 5.0 & 4.4 \\
\hline Ownership of agricultural land & Yes (\%) & 24.8 & 36.8 \\
\hline Involvement in tourism & Yes (\%) & 20.2 & 34.1 \\
\hline Previous participatory experiences & Mean number & & 0.98 \\
\hline
\end{tabular}

\subsection{Questionnaire}

\subsubsection{Dependent Variables}

The willingness to participate was measured by presenting four different narrative scenarios reflecting a different degree of participation $(1=$ reading of information material provided; 2 = visit of a public information and discussion event; 3 = active involvement in a thematic working group; 4 = leading of such a working group). The interviewees were asked to rate the probability of carrying out the proposed behaviour on a scale from 1-10 ( 1 = definitely; $10=$ not at all). In Austria, participatory processes in rural development are quite common. Thus, this range of scenarios reflects the most common roles of the local population in participatory processes.

\subsubsection{Independent Variables}

\section{Theory of Planned Behaviour Dimensions}

The willingness to participate was measured by a set of items based on the Theory of Planned Behaviour (TPB) [30] and validated statements used in previous studies [42,43]. All statements on items linked to the TPB followed a 7-point answer scale $(1=$ fully agree, 7 = do not agree at all). 
Attitude towards Behaviour

The attitude towards participation was measured by items for behavioural beliefs and outcome evaluations. Behavioural beliefs were measured by asking whether the respondents thought that being part of a participatory process is a positive experience and whether participatory processes create better results for initiatives such as the establishment of a biosphere reserve based on their experiences. Outcome evaluations were measured by asking whether it is important for interviewees to become engaged in regional development and to actively integrate local knowledge, concerns and expectations.

\section{Perceived Behavioural Control}

This dimension comprises items on control beliefs and the influence of control beliefs. Control beliefs were measured by asking whether interviewees feel comfortable in a working group, whether they think that results will be considered by authorities and how they assess the extent of personal effort needed. The influence of control beliefs was measured by asking how these beliefs affect their decision to participate.

\section{Social Norms}

The items for measuring social norms included statements on normative beliefs and the motivation to comply. Normative beliefs included items asking whether people close to the respondents and society would expect and appreciate the participation. The items on the motivation to comply included statements on the importance of what society and friends thought about the respondent and how this affected his/her decisions.

\section{Place Attachment}

Place attachment was measured by means of the three-dimensional model (place identity, place dependence and social bonding) [44] (Figure 2). The place identity and place dependence items were selected from a larger set used by Williams and Vaske [45], which were used in previous place attachment studies (e.g., [46]).

\section{Self-Efficacy Beliefs}

In addition, several statements asked for a personal assessment of individual characteristics as an additional dimension (Figure 2). It serves to identify additional parameters which might be essential for becoming active in participatory processes such as the preference to discuss issues of regional development generally, or to discuss these issues with experts or local authorities.
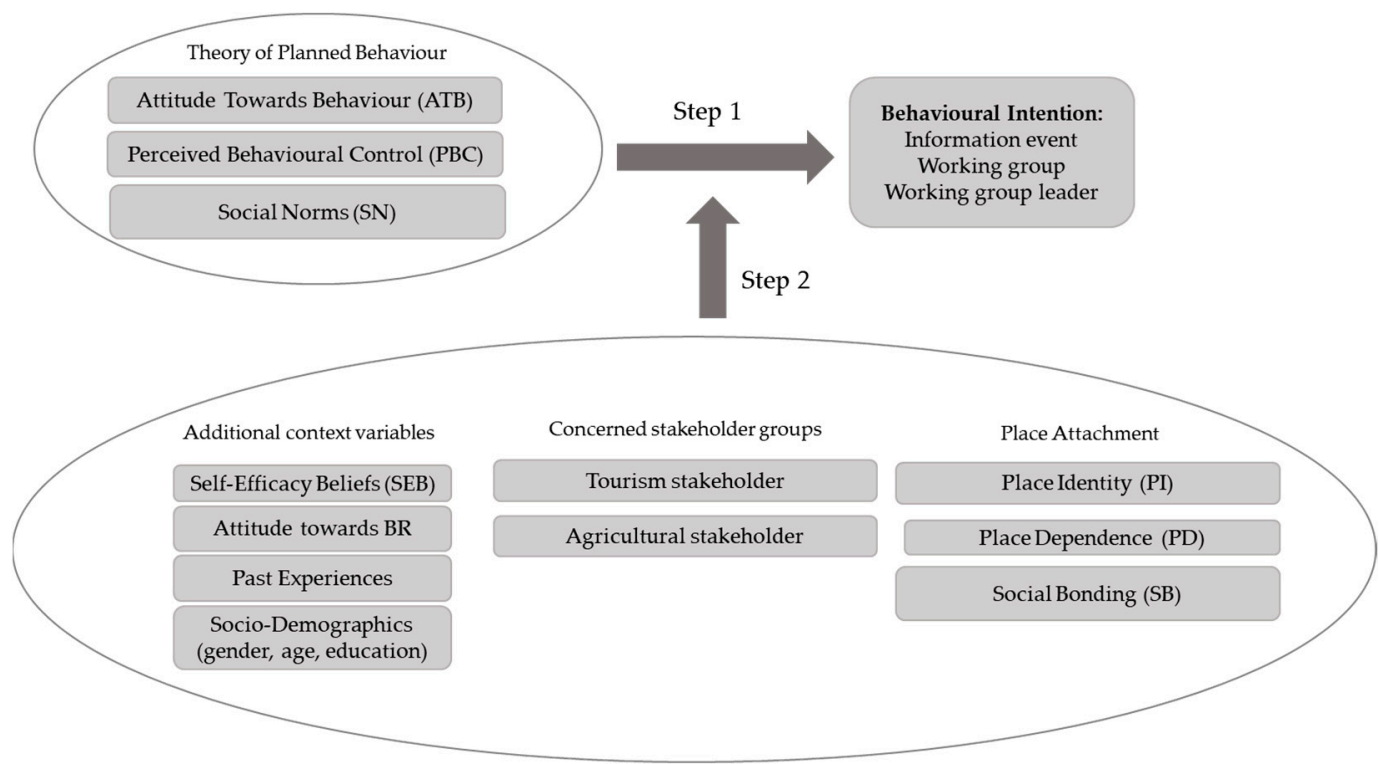

Figure 2. Dependent variables (behavioural intention) and independent variables (authors' draft). 


\subsection{Analyses}

A Cronbach's Alpha (CA) assessed the reliability of the individual TPB dimensions resulting in the elimination of selected statements. Four items were subject to an inversion of the scales. Linear multiple regression analyses determined the extent of the influence of place attachment dimensions, socio-economic factors as well as of the individual dimensions of the TPB on the willingness to participate. The authors used the intended degree of participation as the dependent variable and applied a sequential approach.

The analyses included the dependent variables "information event", "working group" and "working group leader" in the regression models. The variable "reading an information brochure" was discarded due to insufficient variation in the answer scale.

The basic model included the dimensions of TPB (ATB; SN, PBC), and the extended model additionally included all other potential influencing factors (place attachment dimensions; socio-economic factors, SEB, previous experience attitudes towards the biosphere reserve, land ownership and tourism involvement). Data were analysed using SPSS 24.0. A significance level of $p<0.05$ was chosen.

\section{Results}

\subsection{Sample Characteristics}

More men (54.4\%) than women were in the sample. Men were older than the female respondents. The respondents were comparatively well educated. Almost half of them held either a university degree or at least A-levels, whereas people with a completed apprenticeship (26\%), master craftsmen $(12 \%)$ or with no or only primary education $(9 \%)$ were underrepresented (Table 1). A comparatively large proportion of the respondents owned agricultural or forest land (37\%) or worked in the tourism sector (34\%). About $28 \%$ of the respondents stated that they had previous participatory experiences (Table 1).

\subsection{Intended Degree of Participation: Dependent Variables}

Almost all participants (93\%; answers between 1 and 4 ) intended to read the information material $($ mean $=1.86 ; \mathrm{SE}=0.08)$. A vast majority $(79 \%$; answers between 1 and 4$)$ stated that they intended to visit information events (mean $=3.00 ; \mathrm{SE}=0.11$ ), and almost half of the respondents ( $49 \%$; answers between 1 and 4 ) could imagine participating in a working group $($ mean $=5.06 ; \mathrm{SE}=1.14)$ (Table 2$)$. The smallest group of respondents $(24 \%$; answers between 1 and 4 ) were ready to take the lead of a working group (mean $=7.19$; $\mathrm{SE}=0.14)$.

The survey observed a quite strong to low level of participation (information event) amongst all social groups. Male residents and those who owned agricultural land or were involved in tourism showed particularly high interest. Landowners and tourism stakeholders also showed the strongest interest in becoming involved in a working group. When it comes to leading a working group, the tourism stakeholders showed the strongest interest (see Table 2).

Table 2. Intended degree of participation of respondents; likeliness of participation $(1=$ definitely; $10=$ not at all $) ;{ }^{*} p<0.05$, ${ }^{* *} p<0.01,{ }^{* * *} p<0.001$.

\begin{tabular}{|c|c|c|c|c|}
\hline Variable & Levels & Information Event & Working Group & $\begin{array}{l}\text { Leading Working } \\
\text { Group (Mean/SE) }\end{array}$ \\
\hline Degree of intended participation & & $3.00(0.11)$ & $5.06(1.44)$ & $7.19(0.14)$ \\
\hline Age & Mean & $\mathrm{r}_{\mathrm{p}}=-0.130^{* *}$ & n.s. & $r_{p}=0.112 *$ \\
\hline Gender & $\begin{array}{c}\text { Female }(\%) \\
\text { Male }(\%) \\
t \text {-Test }(\mathrm{m} / \mathrm{f})\end{array}$ & $\begin{aligned} & 3.29 \\
& 2.73 \\
\mathrm{t}=- & -2.320 *\end{aligned}$ & $\begin{array}{l}5.36 \\
4.79 \\
\text { n.s. }\end{array}$ & $\begin{array}{c}7.61 \\
6.86 \\
\mathrm{t}=- \\
-2.498 *\end{array}$ \\
\hline Ownership of agricultural land & $\begin{array}{c}\text { Yes }(\%) \\
t \text {-Test }(\mathrm{y} / \mathrm{o})\end{array}$ & $\begin{array}{l}2.83(0.179) \\
\text { n.s. }\end{array}$ & $\begin{array}{l}4.59(0.229) \\
\mathrm{t}=-2.429 *\end{array}$ & $\begin{array}{c}6.87(0.232) \\
\text { n.s. }\end{array}$ \\
\hline Involvement in tourism & $\begin{array}{c}\text { Yes }(\%) \\
t \text {-Test }(y / n)\end{array}$ & $\begin{array}{l}2.72(0.192) \\
\text { n.s. }\end{array}$ & $\begin{array}{c}4.19(0.242) \\
t=-4.368 * * *\end{array}$ & $\begin{array}{c}6.44(0.257) \\
t=-3.362 * * *\end{array}$ \\
\hline
\end{tabular}




\subsection{Independent Variables}

The independent variables of the first step of the analysing process included the dimensions according to the TPB (Table 2): the attitude towards behaviour (in this case, participation) (ATB; 4 items; $\mathrm{CA}=0.846$ ), and social norms (SN; 7 factors).

The added independent variables of the second step, which comprised the place attachment dimensions, were: place identity (PI; four items; $\mathrm{CA}=0.916)$, place dependence ( $\mathrm{PD}$; four items; $\mathrm{CA}=0.812$ ) and social bonding $(\mathrm{SB}$; four items; $\mathrm{CA}=0.738)$. In addition, there were self-efficacy beliefs (SEB; five items; $\mathrm{CA}=0.876$ ), the attitude towards the $\mathrm{BR}$ and socio-demographic items, such as gender, age and education level. Age and education level entered the model as ordinal variables. As an approximation to the level of concern, the ownership of agricultural land and working in the tourism sector were included.

Amongst the respondents, a very positive attitude towards participation was observed. The vast majority considered participation and local knowledge as essential for achieving better results, emphasised the importance of participatory processes and strongly agreed that the BR should not be exclusively planned by experts or public authorities (Table 3). The majority agreed that they would appreciate contributing to regional development. However, they also stated that their social environment did not expect them to become active, even though they expected social recognition if they got involved. The results also showed that time availability is a major consideration for active involvement (Table 3).

The findings showed a positive correlation between the number of participatory processes in the past and the expectation to derive personal benefits $\left(\mathrm{r}_{\mathrm{p}}=-0.156, p<0.01\right)$. Past experiences with participatory processes also indicated a higher readiness to become active $\left(r_{p}=-0.123, p<0.01\right)$ and less concerns regarding the time and resources needed $\left(r_{p}\right.$ $=-0.119, p<0.05)$. The respondents showed high attachment to their region (Table 3) with the highest agreement on place identity.

Table 3. Items and reliability of TPB dimensions (mean, standard error, Cronbach's alpha of dimension (CA)). Final statements included in the model. Eliminated statements excluded. ( 1 = fully disagree; 7 = fully agree).

\begin{tabular}{|c|c|c|c|}
\hline Statement & Mean (SE) & CA & Dimension \\
\hline $\begin{array}{c}\text { A broad participatory process leads to better results } \\
\text { and planning. }\end{array}$ & $1.94(0.064)$ & \multirow{4}{*}{0.846} & \multirow{4}{*}{ Attitude towards behaviour (ATB) } \\
\hline $\begin{array}{l}\text { The consideration of local knowledge in a planning } \\
\text { process is important. }\end{array}$ & $1.85(0.059)$ & & \\
\hline $\begin{array}{c}\text { Numerous offers to participate in a planning process } \\
\text { are important. }\end{array}$ & $1.95(0.057)$ & & \\
\hline $\begin{array}{l}\text { Keeping a local participation process as broad as } \\
\text { possible is desirable. }\end{array}$ & $1.85(0.059)$ & & \\
\hline $\begin{array}{c}\text { Persons who are important to me appreciate if I } \\
\text { become active in regional development. }\end{array}$ & $3.22(0.077)$ & \multirow{7}{*}{0.813} & \multirow{7}{*}{ Social norms (SN) } \\
\hline $\begin{array}{l}\text { Friends and my social environment expect that I get } \\
\text { engaged in this project in the Lungau. }\end{array}$ & $4.88(0.091)$ & & \\
\hline $\begin{array}{l}\text { If I personally get involved, my social environment } \\
\text { will acknowledge this. }\end{array}$ & $3.80(0.084)$ & & \\
\hline $\begin{array}{l}\text { What friends and my social environment think of } \\
\text { my actions is important to me. }\end{array}$ & $3.37(0.085)$ & & \\
\hline $\begin{array}{l}\text { If my friends get involved in an action, it is } \\
\text { important to me that I also participate. }\end{array}$ & $3.63(0.085)$ & & \\
\hline $\begin{array}{l}\text { If I get involved, the support and acknowledgement } \\
\text { of my family is important to me. }\end{array}$ & $2.95(0.093)$ & & \\
\hline $\begin{array}{l}\text { Becoming active in a participatory process creates a } \\
\text { feeling of doing something positive for my region. }\end{array}$ & $2.86(0.079)$ & & \\
\hline
\end{tabular}


Table 3. Cont.

\begin{tabular}{|c|c|c|c|}
\hline Statement & Mean (SE) & CA & Dimension \\
\hline $\begin{array}{c}\text { My time availability is a limiting factor for getting } \\
\text { involved. }\end{array}$ & $4.55(0.090)$ & \multirow{6}{*}{0.771} & \multirow{6}{*}{ Perceived behavioural control (PBC) } \\
\hline $\begin{array}{l}\text { Permanent participation in the biosphere reserve } \\
\text { would be a burden for me. }\end{array}$ & $4.60(0.092)$ & & \\
\hline $\begin{array}{l}\text { I doubt that an active involvement carries benefits } \\
\text { for me. }\end{array}$ & $3.94(0.092)$ & & \\
\hline $\begin{array}{l}\text { My personal situation such as work or kids affects } \\
\text { my ability to get involved. }\end{array}$ & $3.93(0.096)$ & & \\
\hline $\begin{array}{c}\text { Actively participating in a working group causes } \\
\text { stress for me. }\end{array}$ & $3.86(0.086)$ & & \\
\hline $\begin{array}{l}\text { The personally assumed time needed affects my } \\
\text { decision to participate. }\end{array}$ & $4.68(0.071)$ & & \\
\hline $\begin{array}{l}\text { I enjoy discussing with others important issues of } \\
\text { the Lungau region. }\end{array}$ & $2.59(0.074)$ & \multirow{5}{*}{0.876} & \multirow{5}{*}{ Self-efficacy beliefs (SEB) } \\
\hline I love discussing the Lungau region in larger groups. & $3.80(0.090)$ & & \\
\hline $\begin{array}{c}\text { If I have good ideas, I can easily convince others of } \\
\text { them. }\end{array}$ & $3.28(0.074)$ & & \\
\hline $\begin{array}{c}\text { I am a person who is strongly engaged in the } \\
\text { Lungau region. }\end{array}$ & $3.16(0.085)$ & & \\
\hline $\begin{array}{l}\text { I like to discuss with experts and representatives of } \\
\text { the Lungau region. }\end{array}$ & $4.24(0.094)$ & & \\
\hline I enjoy living in the Lungau region. & $1.23(0.026)$ & \multirow{4}{*}{0.916} & \multirow{4}{*}{ Place identity (PI) } \\
\hline The Lungau region is something special to me. & $1.33(0.032)$ & & \\
\hline The Lungau region has a special meaning for me. & $1.39(0.037)$ & & \\
\hline I feel intensely connected with the Lungau region. & $1.43(0.039)$ & & \\
\hline $\begin{array}{l}\text { I prefer living in my community to living in another } \\
\text { community outside the region. }\end{array}$ & $1.90(0.050)$ & \multirow{4}{*}{0.812} & \multirow{4}{*}{ Place dependence (PD) } \\
\hline $\begin{array}{c}\text { Living in the Lungau region satisfies me more than } \\
\text { living in another region. }\end{array}$ & $2.10(0.054)$ & & \\
\hline $\begin{array}{c}\text { No other region can be compared with the Lungau } \\
\text { region. }\end{array}$ & $2.41(0.058)$ & & \\
\hline $\begin{array}{l}\text { I wouldn't live in any other place than the place I } \\
\text { live currently. }\end{array}$ & $2.41(0.061)$ & & \\
\hline $\begin{array}{l}\text { If I moved away from the Lungau region, I would } \\
\text { lose a lot of friends. }\end{array}$ & $1.95(0.052)$ & \multirow{4}{*}{0.738} & \multirow{4}{*}{ Social bonding (SB) } \\
\hline $\begin{array}{l}\text { My family and my friends would be surprised if I } \\
\text { moved out of the Lungau region. }\end{array}$ & $2.01(0.058)$ & & \\
\hline My whole family lives in the Lungau region. & $2.80(0.072)$ & & \\
\hline All of my friends live in the Lungau region. & $2.98(0.059)$ & & \\
\hline
\end{tabular}

\subsection{Modelling Participation}

\subsubsection{Model "Information Event"}

The model including the TPB dimensions showed a significant influence of all factors on the likeliness to participate in an information event, explaining 31\% of the total variance. All items positively predicted the willingness to participate (Table 4).

The extended model with the inclusion of all further factors explained $36 \%$ of the total variance. Place identity had a positive influence, whereas social bonding had a negative influence on the decision to visit an information event. SEB showed the strongest influence, indicating that people with an interest in discussions were more likely to become involved. Neither gender, age, education, the attitude towards the BR, land ownership, tourism involvement nor past participation experience showed a significant influence. 
Table 4. Linear logistic regression: influence of different factors to becoming engaged. Dependent variables: willingness to visit an information event/work in a working group/leading a working group. Independent variables: perceived behavioural control; social norms; attitude towards behaviour; place attachment dimensions and socio-demographics $(n=449)$. Two-step analysis, first with TPB dimensions, and second model with further inclusion of other variables. ${ }^{*} p<0.05,{ }^{* *} p<0.01,{ }^{* * *} p<0.001$.

\begin{tabular}{|c|c|c|c|c|c|c|}
\hline & $\begin{array}{l}\text { Information } \\
\text { Event (Step 1) }\end{array}$ & $\begin{array}{l}\text { Information } \\
\text { Event (Step 2) }\end{array}$ & $\begin{array}{c}\text { Working } \\
\text { Group (Step 1) }\end{array}$ & $\begin{array}{c}\text { Working } \\
\text { Group (Step 2) }\end{array}$ & $\begin{array}{l}\text { Group Leader } \\
\quad \text { (Step 1) }\end{array}$ & $\begin{array}{l}\text { Group Leader } \\
\text { (Step 2) }\end{array}$ \\
\hline & $\mathrm{B}(\mathrm{SE})$ & B (SE) & $\mathrm{B}(\mathrm{SE})$ & B (SE) & B (SE) & B (SE) \\
\hline Constant & $* * * 2.984(0.393)$ & $* * * 2.521(0.684)$ & *** $5.060(0.912)$ & $* * * 3.276(0.813)$ & $* * * 7.200(0.713)$ & $* * * 5.680(0.802)$ \\
\hline ATB & $* * * 0.742(0.084)$ & $* * * 0.596(0.104)$ & $* * * 0.625(0.236)$ & $* * * 0.770(0.124)$ & $0.208(0.279)$ & $* * * 0.483(0.122)$ \\
\hline PBC & $* * * 0.675(0.094)$ & $* * * 0.456(0.101)$ & $* * * 1.480(0.117)$ & $* * * 1.398(0.120)$ & $* * * 1.563(0.135)$ & $* * * 1.450(0.119)$ \\
\hline $\mathrm{SN}$ & $* * * 0.911(0.127)$ & $* * * 0.681(0.110)$ & $* * 1.149(0.101)$ & $* * * 1.044(0.131)$ & $* * * 0.979(0.211)$ & $* * * 0.949(0.315)$ \\
\hline PD & & $0.005(0.098)$ & & $-0.218(0.116)$ & & $\begin{array}{c}* * *-0.398 \\
(0.115)\end{array}$ \\
\hline PI & & * $0.196(0.097)$ & & $0.107(0.115)$ & & $0.096(0.114)$ \\
\hline SB & & * $-0.210(0.097)$ & & $-0.218(0.115)$ & & $\begin{array}{c}* *-0.368 \\
(0.114)\end{array}$ \\
\hline SEB & & $* * * 0.452(0.106)$ & & $* * * 0.399(0.126)$ & & $* * * 0.433(0.124)$ \\
\hline Gender $^{\mathrm{a}}$ & & $0.152(0.198)$ & & $0.125(0.235)$ & & $0.243(0.232)$ \\
\hline Age group $b$ & & $-0.085(0.061)$ & & $* * 0.207(0.073)$ & & $* * * 0.289(0.072)$ \\
\hline Education ${ }^{\mathrm{c}}$ & & $0.037(0.042)$ & & $0.031(0.050)$ & & $0.036(0.049)$ \\
\hline Past & & & & & & \\
\hline $\begin{array}{l}\text { participation } \\
\text { experiences } d\end{array}$ & & $-0.304(0.216)$ & & $-0.050(0.041)$ & & $-0.373(0.253)$ \\
\hline $\begin{array}{c}\text { Attitude } \\
\text { towards BR }{ }^{\mathrm{e}}\end{array}$ & & $0.276(0.178)$ & & $-0.408(0.211)$ & & ${ }^{*}-0.519(0.208)$ \\
\hline $\begin{array}{l}\text { Ownership of } \\
\text { agricultural } \\
\text { land }^{\mathrm{f}}\end{array}$ & & $-0.003(0.201)$ & & $0.271(0.239)$ & & $0.251(0.236)$ \\
\hline $\begin{array}{l}\text { Involvement in } \\
\text { tourism } \mathrm{g}\end{array}$ & & $0.051(0.209)$ & & $0.405(0.248)$ & & $0.091(0.245)$ \\
\hline$R^{2} / R^{2}$ corr & $0.317 / 0.312$ & $0.379 / 0.358$ & $0.415 / 0.411$ & $0.469 / 0.451$ & $0.377 / 0.373$ & $0.472 / 0.454$ \\
\hline
\end{tabular}

(a: $0=$ male; $1=$ female); (b: $1=16-20$ years; $2=21-30$ years; $3=31-40$ years; $4=41-50$ years; $5=51-60$ years; $6=61-70$ years; $7=>71$ years); (c: 1 = basic or no education; $2=$ apprenticeship; $3=$ master craftsmanship; $4=$ secondary level; $5=$ middle school; $6=$ academy; $7=$ university); $(\mathrm{d}: 0=$ no, $1=$ yes); (e: $1=$ positive; $2=$ indifferent; $3=$ negative); $(\mathrm{f}: 0=$ no, $1=$ yes); $(\mathrm{g}: 0=$ no, $1=$ yes $)$.

\subsubsection{Model "Working Group"}

Similar to the model on the information event, all TPB dimensions increased the readiness to act, explaining $41 \%$ of the total variance for participating in a working group (Table 4). PBC showed a significant influence. ATB showed an influence similar to the information event model.

The inclusion of the additional variables slightly improved the explanatory power of the model, explaining $44 \%$ of the variance. PBC and SN were the strongest predicators, whereas place attachment showed no significant influence. Elder persons with high perceived self-efficacy were more likely to become active. Neither the attitude towards the BR nor land ownership or involvement in the tourism sector were significant predictors.

\subsubsection{Model "Working Group Leader"}

In this model, the ATB was insignificant, but PBC and SN were able to explain $37 \%$ of the total variance (Table 4). In the extended model, low PD and low SB favoured an involvement as a working group leader. All dimensions of the TPB proved to be significant as well as SEB and the age of the respondents.

People with high place dependence and social bonds in the region were less likely to take the lead in a working group. Interviewees with a positive attitude towards the 
BR were more likely to become active, whereas tourism involvement or land ownership played no role.

\section{Discussion}

This study analysed factors influencing local residents' willingness to participate in the planning and management of the Salzburger Lungau \& Kärntner Nockberge Biosphere Reserve prior to a participatory process and official recognition by UNESCO. The dimensions of the Theory of Planned Behaviour [30] seems to have a greater predictive power than the factors identified in previous participation studies.

The findings show that PBC, ATB and SN might be important factors for becoming active, whereas the influence of socio-demographics, the level of concern (i.e., involvement in agriculture or tourism) and the attitude towards the BR seem to be of minor importance, compared to previous findings [11]. Due to a focus on sustainable development and economic development rather than on conservation $[37,38]$, the level of concern seems to be lower than in more strictly protected areas [20].

\subsection{The Willingness to Become Active}

The study found a high readiness to participate across all social strata and levels of participation. These results are consistent with the findings of Weixlbaumer and Coy [47], who investigated the readiness to participate in the Großes Walsertal Biosphere Reserve in Austria, but contradict the findings of Stoll-Kleemann et al. [18]. More recent findings confirmed that the high readiness also translated into action [37]. About $10 \%$ of the respondents of a follow-up survey confirmed to have participated in the development of the biosphere reserve [37]. Consistent with Hypothesis 1 and the findings of Larson and Lach [11], the more laborious the potential involvement is, the less people seem to be ready to get involved. Even considering a potential self-selection bias and the low return rate, the overall willingness to become active was higher than expected by local authorities, given the observed number of participants in past participatory processes in the region [40]. This could indicate that local authorities might underestimate the readiness of the local population to participate in regional planning processes.

\subsection{Factors Influencing the Willingness to Become Active}

This study identified factors affecting the intended degree of participation by applying elements of the Theory of Planned Behaviour and the place attachment concept. All factors of the TPB proved to be significant predicators for the intended participation behaviour. Place attachment, self-perceived abilities, the level of concern and socio-demographics played a minor role.

\subsubsection{Perceived Behavioural Control}

This dimension was an important factor in explaining the readiness to act across all models. Consistent with previous research [11,17], the availability of personal resources (mobility, time) is crucial to becoming active. This may underpin the importance of an appropriate methodological set-up and low entry barriers. It further emphasises the influence of protected area managers, as the set-up of the process, the selection of methods and the motivation of residents is fully within their control.

\subsubsection{Social Norms}

Consistent with previous research $[8,17,43]$, the decision to become active is linked to the social environment, particularly if place attachment is generally high in a region [37,39]. Social norms were a main factor in all models, being in line with previous findings [8]. The normative beliefs of the interviewees had a considerable influence on the decision to participate. Social groups that are less familiar with participation seem to strongly rely on the actions of their friends and family. The strong influence of social acknowledgement and encouragement indicates a difficult situation for management bodies. Failed 
past participatory processes, traditional values discouraging participation or a lack of trust in local authorities might be beyond the sphere of influence but have a strong impact on future participation and are a particular challenge for appropriate and targeted communication [20]. Consequently, it seems to be important for management bodies to communicate and officially appreciate involvement [20]. Furthermore, given that place attachment is high, management bodies may consider broader participatory processes to ensure high acceptance explicitly involving local associations, local multipliers and educational institutions [39].

\subsubsection{Attitude towards Participation and Biosphere Reserves}

The attitude towards participation had an influence in nearly all models, confirming its relevance to predict the readiness to act. Given the highly rated importance of participatory processes, its comparatively low influence is not in line with previous findings $[11,14]$. This might mean that even though broad participatory offers are considered essential, a considerable proportion of the population might already be satisfied by existing participatory opportunities. This is supported by the findings of a follow-up survey in 2019 [37]. On the contrary, a top-down approach without offering opportunities could trigger conflicts as the opportunity itself is rated rather high.

The attitude towards the BR was weakly linked to the readiness to act, as indicated by previous findings $[11,14]$. During the time of the data collection, only a little information about the BR was available. It seems that the public supports the general idea of the BR, without seeing an immediate need to act. Whereas national parks are often confronted with a high readiness to (counter-)act as the populations fears potential restrictions or impacts such as increased wildlife conflicts or restrictions in land use [20], the concept of a biosphere reserve as a rather weak conservation category seems to cause less of a reaction. This might indicate a prevailing attitude that "those in charge" should take care of the issue. This is also in line with the observation that respondents liked to generally discuss regional issues rather than being part of shaping regional development.

\subsubsection{Place Attachment}

Place attachment had an influence on the readiness to act but its influence heavily depended on the place attachment dimension and on the type of participation. Strong identification with the region seemed to favour participation in an information event, indicating a strong interest to be informed about ongoing developments in the region. In contrast, low social bonding and place dependence seemed to favour leading a working group. Although previous findings showed that high place attachment is a driver to becoming active $[11,27,37]$, it seems that those less socially attached to the region, are more likely to take a lead in the participatory processes. This is in line with previous findings, which identified the social environment as a potentially disabling factor, if traditional worldviews prevail [8]. This could also be related to the negative impact of place dependence. It could further indicate that residents are either satisfied with how the region performs or that they are not convinced that a BR would be able to push the further development of the region.

\subsubsection{Perceived Self-Efficacy and Socio-Demographics}

The preference to communicate and discuss in groups proved to be a significant factor favouring participation irrespective of the socio-demographic background. This is in line with previous studies showing the positive influence of personal preferences to becoming involved $[11,14]$. Participatory processes seem to attract participants with a preference for lively discussions. However, it may lead to a discouragement of persons, who consider participation as important, but feel uncomfortable with existing participatory offers.

Older people were shown to be more eager to become active in a working group, whereas neither gender nor the education level showed a significant influence, contradicting previous findings $[10,12]$. Even though previous findings indicated a gender gap in participation $[25,26]$, no such gap was observed in the readiness to participate. The similar 
readiness amongst women and men indicates a reality gap and potentially discouraging set-up of participatory processes, as past processes in the study region were dominated by men [40].

\subsubsection{Level of Concern and Previous Participatory Experiences}

As agricultural and tourism stakeholders were supposed to be the most affected stakeholder group, these groups were expected to show a strong interest in becoming involved. Whereas initial results showed a high readiness amongst tourism professionals and (partly) amongst farmers, it proved to be insignificant in the models. This is rather surprising, as previous studies frequently mentioned the level of concern as a key factor $[11,14,18]$. However, the BR management clearly emphasised during the nomination process that sustainable (economic) development is amongst the priorities, whereas conservation issues play a minor role. In addition, the information level at the time of the survey was rather low. The level of concern is likely to change during the planning process once planning becomes more concrete. This was confirmed by a strong participation of farmers in later participatory processes [37]. At the same time, it could also indicate that the influence on willingness might be overestimated.

Even though previous studies indicated a positive influence of experiences gained in participation processes [14], i.e., a higher appreciation of participatory processes and a higher readiness to become active again, no significant influence in the models emerged. However, past experiences might affect the final decision to participate once a process finally starts, as suspected by Schenk [14].

\subsection{Methodological Limitations of the Study}

By applying the elements of the TPB [30], the authors measured the intention to participate but not the actual behaviour. However, this new approach identified additional factors to better understand participation, as it also explicitly included residents who only expressed their interest to participate without finally becoming active.

The set of statements of the TPB was applied in such a context this first time, and thus the further development of standardised factors can be subject to future research. A potential limitation of the study is that it is a single case study with a comparatively low response rate. Potential implications of self-selection cannot be excluded, even though a comparison with official census data shows relatively good representation.

\section{Conclusions}

The study findings contribute to the understanding of the decision of local residents to become actively involved in participatory processes of a biosphere reserve in Austria. The application of constructs of the TPB adds a complimentary perspective for explaining the willingness to become active, prior to the start of a participatory process. Whereas several well described factors, such as the level of concern (land ownership and/or tourism sector involvement) or previous experiences with participatory processes, showed little influence, the TPB dimensions offered more predictive power. This research could provide valuable baseline information for the interpretation of follow-up studies and provide additional elements for the monitoring of participation and its connection with the acceptance of the BR [20] or regional identity [37]. Thus, further applications of this model in different regional and social contexts might be helpful to better understand the relationship between the intended and revealed behaviour and the participatory potential of a region.

The study results underpin the findings of Martinez and McMullin [17] and Buchecker et al. [8] regarding the importance of a social environment. Our results show that in a well-functioning social environment, the readiness to participate is high; however, in a traditional social environment, more effort may be necessary to activate rural residents. It is advisable to include place attachment and consideration of the social environment more strongly in future participatory research and build it into conceptual models explaining people-parks relationships [20]. For future studies, it could be interesting to combine 
this set of statements carried out prior to a participatory process with an investigation of actual participation to compare the intended and revealed behaviour (i.e., the "IntentionBehaviour-Gap" [48]). This would allow for an identification of social groups with a high readiness who are not present in the participatory processes to further customise participatory processes. This remains a challenge, particularly considering the shifting focus from top-down management towards co-management and new forms of governance of protected areas [49]. The findings show the complexity of the final decision to take action. Due to this complexity, future research should explicitly consider citizen-science approaches to include the local cultural and social context, as the population is the immediate user of the outcomes of participatory development research. Initial efforts to integrate the degree of (intended and actual) participation into continuous monitoring have been made by measuring the indicator "satisfaction with participatory opportunities" in the biosphere reserve integrated monitoring (BRIM) scheme of the biosphere reserve [41]. In the future, this could provide longitudinal data to better understand the people-park relationships going beyond a single case study [29].

\section{Management Recommendations}

The findings are relevant for improving participatory processes in protected area planning. The findings underpin the importance of choosing an appropriate methodological approach for a participatory process, given the high relevance of the PBC. It also indicates that the willingness to participate is easily underestimated by management bodies as these usually refer to the actual numbers showing up in a participatory process. Protected area managers may consider testing new participatory methods if social groups are missing in existing processes.

It seems that regardless of the effort made by the management, only a certain percentage of the population is willing to participate. The management may focus its efforts in involving these groups in a representative manner and extend its efforts to missing social groups only. Participation could thus be considered successful, if those striving to be involved are present in a participatory process. Given the high interest in the information events and brochures, management bodies should include these in their participation strategy, offering low level information and discussion opportunities for the broader public.

Author Contributions: Conceptualization, methodology, software, analysis, investigation, data curation and writing (original draft preparation), M.H.; supervision, review and editing, validation, A.A. All authors have read and agreed to the published version of the manuscript.

Funding: This research received no external funding.

Institutional Review Board Statement: All subjects in the study were anonymously labeled and agreed to participate in the study.

Informed Consent Statement: Informed consent was obtained from all subjects involved in the study. The study was conducted in accordance with the Declaration of Helsinki.

Data Availability Statement: The datasets are not available for the public.

Acknowledgments: We want to thank the Regionalverband Lungau (the later Biosphere Reserve Management Body) for supporting the research and bearing the costs for the printing and distribution of the questionnaire.

Conflicts of Interest: The authors declare no conflict of interest. The funders had no role in the design of the study; in the collection, analyses, or interpretation of data; in the writing of the manuscript, or in the decision to publish the results.

\section{References}

1. Borrini, G.; Dudley, N.; Jaeger, T.; Lassen, B.; Neema, P.; Phillips, A.; Sandwith, T. Governance of protected areas: From understanding to action. Best Pract. Prot. Area Guidel. Ser. 2013, 20, 16.

2. Stoll-Kleemann, S.; Welp, M. Participatory and Integrated Management of Biosphere Reserves: Lessons from Case Studies and a Global Survey. GAIA-Ecol. Perspect. Sci. Soc. 2008, 17, 161-168. [CrossRef] 
3. Van Cuong, C.; Dart, P.; Hockings, M. Biosphere reserves: Attributes for success. J. Environ. Manag. 2017, 188, 9-17. [CrossRef]

4. UNECE. Convention on Access to Information, Public Participation in Decision-Making and Access to Justice in Environmental Matters: Done at Aarhus, Denmark, on 25 June 1998; United Nations: New York, NY, USA, 1999; ISBN 9210163370.

5. UNESCO. Lima Action Plan for UNESCO's Man and the Biosphere (MAB) Programme and its World Network of Biosphere Reserves (2016-2025). In Proceedings of the 28th MAB ICC, Lima, Peru, 19 March 2016.

6. Apostolopoulou, E.; Drakou, E.; Pediaditi, K. Participation in the management of Greek Natura 2000 sites: Evidence from a cross-level analysis. J. Environ. Manag. 2012, 113, 308-318. [CrossRef]

7. Onaindia, M.; Ballesteros, F.; Alonso, G.; Monge-Ganuzas, M.; Peña, L. Participatory process to prioritize actions for a sustainable management in a biosphere reserve. Environ. Sci. Policy 2013, 33, 283-294. [CrossRef]

8. Buchecker, M.; Hunziker, M.; Kienast, F. Participatory landscape development: Overcoming social barriers to public involvement. Landsc. Urban Plan. 2003, 64, 29-46. [CrossRef]

9. Cooke, B.; Kothari, U. (Eds.) Participation: The New Tyranny; Zed Books: London, UK, 2001; ISBN 1856497941.

10. Jennewein, J.S.; Jones, K.W. Examining 'willingness to participate' in community-based water resource management in a transboundary conservation area in Central America. Hydrol. Res. 2016, 18, 1334-1352. [CrossRef]

11. Larson, K.L.; Lach, D. Participants and non-participants of place-based groups: An assessment of attitudes and implications for public participation in water resource management. J. Environ. Manag. 2008, 88, 817-830. [CrossRef] [PubMed]

12. Coulibaly-Lingani, P.; Savadogo, P.; Tigabu, M.; Oden, P.-C. Factors influencing people's participation in the forest management program in Burkina Faso, West Africa. For. Policy Econ. 2011, 13, 292-302. [CrossRef]

13. Schieber, K. Analyse zur Akzeptanz des geplanten UNESCO-Biosphärenreservates Schwäbische Alb. In Wahrnehmung und Akzeptanz von Großschutzgebieten; Mose, I., Ed.; Wahrnehmungsgeographische Studien, 25; BIS-Verl. der Carl-von-OssietzkyUniversität: Oldenburg, Germany, 2009; pp. 59-82.

14. Schenk, A. Relevante Faktoren der Akzeptanz von Natur- und Landschaftsschutzmassnahmen: Ergebnisse Qualitativer Fallstudien; Ostschweizerische Geographische Gesellschaft: St. Gallen, Switzerland, 2000; ISBN 3907502051.

15. Stern, M.J.; Coleman, K.J. The Multidimensionality of Trust: Applications in Collaborative Natural Resource Management. Soc. Nat. Resour. 2014, 28, 117-132. [CrossRef]

16. Smith, J.W.; Leahy, J.E.; Anderson, D.H.; Davenport, M.A. Community/Agency Trust and Public Involvement in Resource Planning. Soc. Nat. Resour. 2013, 26, 452-471. [CrossRef]

17. Martinez, T.A.; McMullin, S.L. Factors Affecting Decisions to Volunteer in Nongovernmental Organizations. Environ. Behav. 2004, 36, 112-126. [CrossRef]

18. Stoll-Kleemann, S.; de la Vega-Leinert, A.C.; Schultz, L. The role of community participation in the effectiveness of UNESCO Biosphere Reserve management: Evidence and reflections from two parallel global surveys. Environ. Conserv. 2010, 37, 227-238. [CrossRef]

19. Stoll-Kleemann, S.; O'Riordan, T. From Participation to Partnership in Biodiversity Protection: Experience from Germany and South Africa. Soc. Nat. Resour. 2002, 15, 161-177. [CrossRef]

20. Job, H.; Bittlingmaier, S.; Mayer, M.; von Ruschkowski, E.; Woltering, M. Park-People Relationships: The Socioeconomic Monitoring of National Parks in Bavaria, Germany. Sustainability 2021, 13, 8984. [CrossRef]

21. Zanetell, B.A.; Knuth, B.A. Participation Rhetoric or Community-Based Management Reality? Influences on Willingness to Participate in a Venezuelan Freshwater Fishery. World Dev. 2004, 32, 793-807. [CrossRef]

22. Hernes, M.I.; Metzger, M.J. Understanding local community's values, worldviews and perceptions in the Galloway and Southern Ayrshire Biosphere Reserve, Scotland. J. Environ. Manag. 2017, 186, 12-23. [CrossRef]

23. Josephs, L.I.; Humphries, A.T. Identifying social factors that undermine support for nature-based coastal management. J. Environ. Manag. 2018, 212, 32-38. [CrossRef]

24. Mosler, H.-J. Die Organisation kollektiver Aktionen durch Beeinflussung der individuellen Teilnahmeentscheidung: Eine Simulationsstudie. Die Organisation kollektiver Aktionen durch Beeinflussung der individuellen Teilnahmeentscheidung. Kölner Zeitschrift für Soziologie und Sozialpsychologie 2000, 52, 264-290. [CrossRef]

25. Dungumaro, E.W.; Madulu, N.F. Public participation in integrated water resources management: The case of Tanzania. Phys. Chem. Earth Parts A/B/C 2003, 28, 1009-1014. [CrossRef]

26. Lise, W. Factors influencing people's participation in forest management in India. Ecol. Econ. 2000, 34, 379-392. [CrossRef]

27. Lewicka, M. Ways to make people active: The role of place attachment, cultural capital, and neighborhood ties. J. Environ. Psychol. 2005, 25, 381-395. [CrossRef]

28. Borazjani, A.; Mosapour, S.; Keykha, A.; Sasouli, M. Case Study: Willingness to participation of local communities in the conservation of national parks. Int. J. Hum. Cap. Urban Manag. 2017, 2, 69-76.

29. Von Ruschkowski, E.; Nienaber, B. Akzeptanz als Rahmenbedingung für das erfolgreiche Management von Landnutzungen und biologischer Vielfalt in Großschutzgebieten. Raumforsch. Raumordn. 2016, 74, 525-540. [CrossRef]

30. Ajzen, I. The theory of planned behavior. Organ. Behav. Hum. Decis. Process. 1991, 50, 179-211. [CrossRef]

31. Mannetti, L.; Pierro, A.; Livi, S. Recycling: Planned and self-expressive behaviour. J. Environ. Psychol. 2004, 24, 227-236. [CrossRef]

32. Zeidenitz, C.; Mosler, H.-J.; Hunziker, M. Outdoor recreation: From analysing motivations to furthering ecologically responsible behaviour. For. Snow Landsc. Res. 2007, 81, 175-190. 
33. Liu, J.H.; Sibley, C.G. Attitudes and behavior in social space: Public good interventions based on shared representations and environmental influences. J. Environ. Psychol. 2004, 24, 373-384. [CrossRef]

34. UNESCO. Biosphere Reserves: The Seville Strategy \& the Statutory Framework of the World Network; UNESCO: Paris, France, 1996.

35. Albert, C.; Zimmermann, T.; Knieling, J.; Von Haaren, C. Social learning can benefit decision-making in landscape planning: Gartow case study on climate change adaptation, Elbe valley biosphere reserve. Landsc. Urban Plan. 2012, 105, 347-360. [CrossRef]

36. Eder, R.; Arnberger, A. Local residents' place attachment and the perceived Local residents' place attachment and the perceived benefits for them of the UNESCO Wienerwald Biosphere Reserve. Ecomont 2012, 13. in press.

37. Von Lindern, E.; Knoth-Letsch, R.; Häring, V.; Klenovec, C.; Hunziker, M.; Wallner, A.; Knaus, F. Akzeptanz, Identifikation und Engagement: Ergebnisse und Implikationen aus einer Bevölkerungsumfrage in acht UNESCO Biosphere Reserves in der Schweiz, Deutschland und Österreich. In Biosphäre 4.0; Borsdorf, A., Jungmeier, M., Braun, V., Heinrich, K., Eds.; Springer: Berlin/Heidelberg, Germany, 2020; pp. 121-137.

38. Pütz, M.; Job, H. Governance und Regionalentwicklung in Großschutzgebieten der Schweiz und Österreichs. Raumforsch. Raumordn. 2016, 74, 569-583. [CrossRef]

39. Huber, M.; Arnberger, A. Opponents, waverers or supporters: The influence of place-attachment dimensions on local residents' acceptance of a planned biosphere reserve in Austria. J. Environ. Plan. Manag. 2015, 59, 1610-1628. [CrossRef]

40. Koch, M. Schlüsselakteure und Deren Beziehungen im Entstehungsprozess des Biosphärenparks Lungau: Eine Quantitative Regionale Netzwerkanalyse; GRIN Verlag GmbH: München, Germany, 2011; ISBN 9783656011064.

41. Huber, M.; Köstl, T. Nachhaltigkeit messen—Praktische Erfahrungen und Herausforderungen im Aufbau eines Biosphere Reserve Integrated Monitoring (BRIM) im Biosphärenpark Salzburger Lungau \& Kärntner Nockberge. In Biosphäre 4.0; Borsdorf, A., Jungmeier, M., Braun, V., Heinrich, K., Eds.; Springer: Berlin/Heidelberg, Germany, 2020; pp. 281-302.

42. Francis, J.J.; Eccles, M.P.; Johnston, M.; Walker, A.; Grimshaw, J.; Foy, R.; Kaner, E.F.S.; Smith, L.; Bonetti, D. Constructing Questionnaires Based on the Theory of Planned Behaviour: A Manual for Health Services Researchers; University of Newcastle upon Tyne: Newcastle upon Tyne, UK, 2004.

43. Fielding, K.; McDonald, R.; Louis, W. Theory of planned behaviour, identity and intentions to engage in environmental activism. J. Environ. Psychol. 2008, 28, 318-326. [CrossRef]

44. Kyle, G.; Mowen, A.J.; Tarrant, M. Linking place preferences with place meaning: An examination of the relationship between place motivation and place attachment. J. Environ. Psychol. 2004, 24, 439-454. [CrossRef]

45. Williams, D.R.; Vaske, J.J. The Measurement of Place Attachment: Validity and Generalizability of a Psychometric Approach. For. Sci. 2003, 49, 830-840. [CrossRef]

46. Arnberger, A.; Eder, R. The influence of green space on community attachment of urban and suburban residents. Urban For. Urban Green. 2012, 11, 41-49. [CrossRef]

47. Weixlbaumer, N.; Coy, M. Selbst-und Fremdbild in der Gebietsschutzpolitik. Das Beispiel des Biosphärenparks Großes Walsertal/Vorarlberg. In Wahrnehmung und Akzeptanz von Großschutzgebieten; Mose, I., Ed.; Wahrnehmungsgeographische Studien, 25; BIS-Verl. der Carl-von-Ossietzky-Universität: Oldenburg, Germany, 2009; pp. 37-58.

48. Fishbein, M.; Ajzen, I. Predicting and Changing Behavior. Psychol. Press 2011. [CrossRef]

49. Hammer, T.; Mose, I.; Scheurer, T.; Siegrist, D.; Weixlbaumer, N. Societal research perspectives on protected areas in Europe. Ecomont 2012, 4, 5-12. [CrossRef] 